\title{
Insoluble Content, Ionic Composition, Density, and X-Ray Diffraction Spectra of 6 Evaporites from Niger Republic
}

\author{
Hassidou Saidou, ${ }^{1,2}$ Ahmed Hichem Hamzaoui, ${ }^{2}$ and Adel Mnif ${ }^{2}$ \\ ${ }^{1}$ Department of Chemistry, Faculty of Sciences and Techniques, University of Maradi, 410 Maradi, Niger \\ ${ }^{2}$ Laboratory of Recovery of Valuable Materials, National Center for Research in Materials Sciences, \\ 8027 Soliman, Nabeul, Tunisia
}

Correspondence should be addressed to Hassidou Saidou; saidouhassidou@gmail.com

Received 23 October 2014; Revised 11 March 2015; Accepted 12 March 2015

Academic Editor: Isiaka A. Ogunwande

Copyright (C) 2015 Hassidou Saidou et al. This is an open access article distributed under the Creative Commons Attribution License, which permits unrestricted use, distribution, and reproduction in any medium, provided the original work is properly cited.

Some physicochemical (insoluble content, ionic composition, density, and X-ray diffraction spectra) characteristics of Nigerien evaporites were investigated in this study. The results obtained showed that trona is the main mineral contained in Agadez, Dirkou, Niamey, and Zinder evaporites while thenardite and halite constitute the major minerals in Bilma and Tabalak evaporites, respectively. In addition, all evaporites samples investigated revealed the presence of quartz and halite. Other interesting minerals (calcite, gypsum, sylvite, aphthitalite, nahcolite, illite, burkeite, kaolinite, griceite, and talc) were also detected. The use of Agadez, Dirkou, Niamey, and Zinder evaporites as catalyst to accelerate cowpea cooking is due to bicarbonates ions present in trona. Bilma and Tabalak evaporites employed in animal feeding are due to the halite contained in a significant quantity.

\section{Introduction}

Several studies about evaporites have been published [1-4]. In fact, the results of Cordier et al. [2] suggested the possibility of large abundances of butane and acetylene in Titan's dry lakebed evaporites, while Alonso-Azcárate et al. [3] showed that strontium isotopic ratios of the Spain Cameros Basin evaporites are elevated compared to the Keuper source. Martin et al. [4] showed, in their study about Cenozoic Turkish evaporites, that seawater was the dominant source of sulphate and strontium.

Otherwise, trona is a salt commonly used in east, west, and central Africa and it is the second most used salt in Nigerian homes [5]. This salt is derived from deposits formed by the evaporation of inland lakes [6]. Deposits of trona (a nonmarine evaporite mineral) are relatively uncommon compared to many other evaporites, such as gypsum and halite. In fact, there are 26 significant deposits of gypsum and 15 of halite, but only two yielded trona $[7,8]$. An important number of authors have reported the uses of trona in the east African trona [9-11]. Thus, in east Africa, trona is used in cooking tough food materials such as beans and maize, due to its property of softening them rapidly, as a prophylactic, as a feed supplement to cattle and goats. It is also ground with tobacco in the preparation of snuff. The investigation of Emebiri and Nwufo [12] suggested that trona may have considerable potential for reducing damage to stored maize grains. In Niger, Kanwa (local name of evaporite) is also used to heal stomach pain. The aim of this study is to characterize the evaporites of six areas of Niger.

\section{Material and Methods}

Evaporites samples were taken in Agadez, Bilma, Dirkou, Niamey, Tabalak, and Zinder areas of Niger, Africa. Each sample is designated by the first letter, in capital, of the name of the locality, except Tabalak which is designated by X (see map in Figure 1).

Note that Tabalak does not appear in the map. It is located in the department of Abalak in the region of Tahoua.

2.1. Preliminary Analysis. X-rays diffraction spectra (using Phillips X'PERT PRO diffractometer model) of six raw 
samples from Agadez, Bilma, Dirkou, Niamey, Tabalak, and Zinder, previously ground, were implemented.

2.2. Determination of the Percentage of Insoluble. Two grams of each sample was weighted with a precision balance (Mettler MT-2000 model) and introduced in a beaker. Then, after adding $100 \mathrm{~cm}^{3}$ of ultrapure water, each sample was stirred magnetically for a duration of 20 mins and filtered using $0.45 \mu \mathrm{m}$ filter. The remaining solid was dried at $100^{\circ} \mathrm{C}$ for a period of 4 hours in an oven and placed in a desiccator, after which the solid was weighted and its percentage was determined as follows:

$$
\text { solid } \%=\frac{\left(m_{1}-m_{0}\right)}{m_{\text {P.E. }}} \times 100 .
$$

$m_{0}$ is mass of filter; $m_{1}$ is mass of filter + mass of solid; $m_{\text {P.E. }}$ is mass of test sample.

The percentage of ions was determined as follows:

$$
\text { Ion } \%=\left(\frac{C_{\text {ion }}}{C_{\mathrm{ev}}}\right) \times 100,
$$

where $C_{\text {ion }}$ is the concentration of the ion and $C_{\mathrm{ev}}$ is the concentration of sample.

Note that $C_{\text {ion }}$ and $C_{\mathrm{ev}}$ are expressed in gram per litre.

The X-ray diffraction spectra of dried solids were also recorded.

2.3. Determination of Ionic Composition. The filtrate obtained was recovered to determine the ionic composition of each sample. Thus, the concentrations of sodium, potassium, chloride, bicarbonate, iron, sulphate, magnesium, and ions were determined. Sodium and potassium were determined with a flame photometer, type BWB technologies. Chloride was determined potentiometrically with a potentiometer type 716 DMS Titrino. Bicarbonate was determined using a volumetric method. Iron, magnesium, and calcium were determined by atomic absorption with a spectrophotometer type AAS Vario6. Sulphate was determined by gravimetric method using barium chloride reagent.

2.4. Density Measurement of Sample D. Sample D was taken as example to determine its density. Thus, $10 \mathrm{~g}$ of this sample (previously ground) was dissolved in $30 \mathrm{~cm}^{3}$ of ultrapure water. After filtration, the weight of 5, 10, 15, 20, 25, and $30 \mathrm{~cm}^{3}$ was recorded using a precision balance. The density $d\left(\mathrm{~g} \cdot \mathrm{cm}^{-3}\right)$ is

$$
d=\frac{m_{1}}{5}=\frac{m_{2}}{10}=\frac{m_{3}}{15}=\frac{m_{4}}{20}=\frac{m_{5}}{25}=\frac{m_{6}}{30},
$$

where $m_{1}, m_{2}, m_{3}, m_{4}, m_{5}$, and $m_{6}$ are the mass in $g$ of 5,10 , $15,20,25$, and $30 \mathrm{~cm}^{3}$ of filtrate obtained.

2.5. Recrystallization Experiment. After determining the density, $15 \mathrm{~mL}$ of the filtrate was introduced into a crystallizer and aerated at room temperature. After 7 days, white crystals were

\begin{tabular}{|c|c|c|c|c|c|c|}
\hline \multirow{2}{*}{$\begin{array}{l}\text { Minerals } \\
\text { detected }\end{array}$} & \multicolumn{6}{|c|}{ Samples } \\
\hline & $\mathrm{A}$ & B & $\mathrm{D}$ & $\mathrm{N}$ & $\mathrm{X}$ & $\mathrm{Z}$ \\
\hline Trona & $x$ & & $x$ & $x$ & & $x$ \\
\hline Quartz & $\times$ & $x$ & $\times$ & $\times$ & $\times$ & $x$ \\
\hline Halite & $x$ & $x$ & $\times$ & $\times$ & $x$ & $x$ \\
\hline Sylvite & $x$ & & & $\times$ & $\times$ & $x$ \\
\hline Calcite & $\times$ & $x$ & $\times$ & & & $x$ \\
\hline Aphthitalite & $x$ & $x$ & $x$ & $\times$ & & \\
\hline Thenardite & & $x$ & & & & \\
\hline Gypsum & & & & & $x$ & $x$ \\
\hline Burkeite & & $\times$ & $\times$ & & & $x$ \\
\hline Nahcolite & & & $\times$ & & & $x$ \\
\hline Illite & & & $\times$ & $\times$ & & $x$ \\
\hline
\end{tabular}

TABLE 1: Minerals detected from X-rays analysis of raw samples studied ( $\times$ : minerals detected in samples studied).

formed. X-rays diffraction spectrum of crystals obtained was recorded using the same $\mathrm{X}$-rays diffractometer as previously.

The remaining $15 \mathrm{~mL}$ was also introduced into a crystallizer and placed in a refrigerator. After $30 \mathrm{~min}$, white crystals were also formed as previously mentioned. X-rays diffraction spectrum was also recorded.

\section{Results and Discussions}

Figure 1 showed the $\mathrm{X}$-rays diffraction spectra of the samples studied ( $A, B, D, N, X$, and $Z$ ). The minerals detected in each sample and the corresponding chemical formulas are mentioned in Table 1.

The X-rays spectra of samples investigated (Figure 2 and Table 1) showed that all evaporite samples investigated contained quartz $\left(\mathrm{SiO}_{2}\right)$ and halite $(\mathrm{NaCl})$. The last mineral (mean by last mineral halite $(\mathrm{NaCl})$ ) has also been detected in all evaporite samples studied by Nielsen [13]. However, the same author has observed the presence of quartz, only in Sudan and northern Tanzania evaporite. Trona $\left(\mathrm{Na}_{3} \mathrm{H}\left(\mathrm{CO}_{3}\right)_{2} \cdot 2 \mathrm{H}_{2} \mathrm{O}\right)$ is present in samples $\mathrm{A}, \mathrm{D}, \mathrm{N}$, and $\mathrm{Z}$. This mineral has been detected by Nielsen during his study of east African magadi [13]. Sylvite $(\mathrm{KCl})$ was detected in evaporites $\mathrm{A}, \mathrm{N}, \mathrm{X}$, and $\mathrm{Z}$ while calcite was observed in $\mathrm{A}, \mathrm{B}, \mathrm{D}$, and $\mathrm{Z}$. Thenardite $\left(\mathrm{Na}_{2} \mathrm{SO}_{4}\right)$ was detected only in evaporite $\mathrm{B}$. This mineral has been used previously with sylvite to obtain arcanite $\left(\mathrm{K}_{2} \mathrm{SO}_{4}\right)$, a good fertilizer rarely found in nature [14]. Other minerals (aphthitalite, gypsum, burkeite, nahcolite, and illite) were also detected in minor proportion. Burkeite $\mathrm{Na}_{4}\left(\mathrm{SO}_{4}\right)_{1.45}\left(\mathrm{CO}_{3}\right)_{0.55}$ has been also observed, earlier, in Lake Katwe by Nielsen [13]. Evaporites A, D, N, and Z were used to accelerate cooking cowpea. This property is due to bicarbonates ions contained in trona. These ions are known to reduce the time of cooking food. This result is in agreement with the studies of Ankrah and Dovlo (1978) [10], Uzogara et al. (1990) [15], and Sodipo [16]. Evaporites A, D, and Z have also therapeutic virtues in Niger. Indeed aqueous solutions of these evaporites are used, by oral way, to heal stomach pain. Aqueous solutions of 


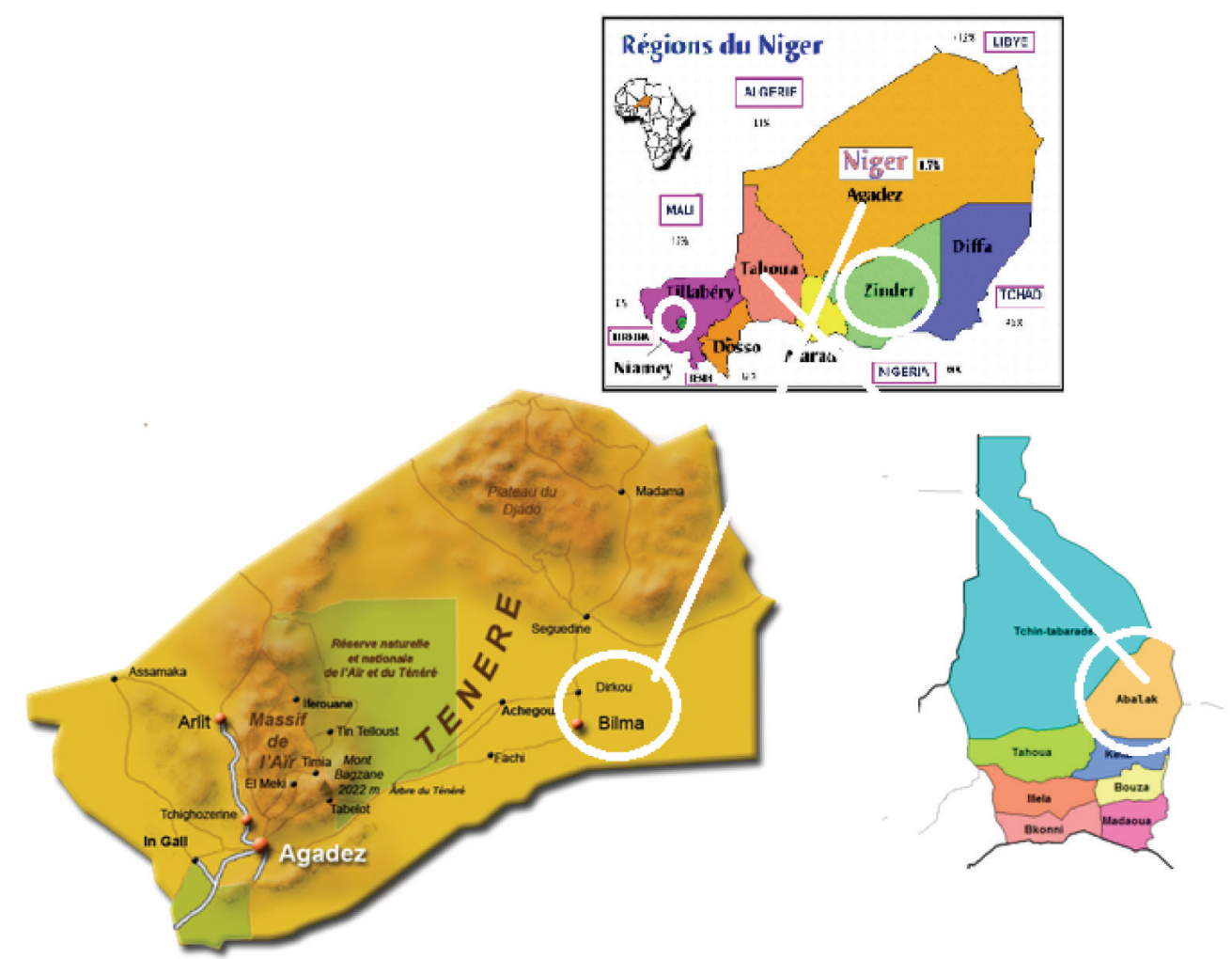

FIGURE 1: Map of Niger and the sampling different localities.

TABLE 2: $\mathrm{pH}$ and percentage of insoluble and some ions in the samples studied.

\begin{tabular}{lccccccccc}
\hline Samples & $\mathrm{pH}$ & Insoluble $(\%)$ & $\mathrm{Na}^{+}(\%)$ & $\mathrm{K}^{+}(\%)$ & $\mathrm{Fe}^{2+}(\%)$ & $\mathrm{Mg}^{2+}(\%)$ & $\mathrm{Cl}^{-}(\%)$ & $\mathrm{SO}_{4}^{2-}(\%)$ & $\mathrm{HCO}_{3}^{-}(\%)$ \\
\hline $\mathrm{A}$ & 9.85 & 1.285 & 15.251 & 0.775 & 0.0057 & 0.00001 & 5.282 & 0.26 & 69.387 \\
$\mathrm{~B}$ & 8.60 & 36.64 & 14.100 & 2.750 & 0.0032 & 0.000043 & 11.526 & 3.41 & 5.846 \\
$\mathrm{D}$ & 9.75 & 7.18 & 19.220 & 0.412 & 0.0046 & 0.00028 & 20.062 & 1.71 & 51.408 \\
$\mathrm{~N}$ & 9.90 & 1.40 & 14.375 & 0.787 & 0.0084 & 0 & 4.441 & 0.46 & 66.084 \\
$\mathrm{X}$ & 7.00 & 14.29 & 21.500 & 0.091 & 0.0048 & 0.000402 & 63.062 & 0.04 & 1.271 \\
$\mathrm{Z}$ & 9.90 & 24.47 & 13.750 & 2.875 & 0.0044 & 0 & 10.767 & 0.165 & 44.479 \\
\hline
\end{tabular}

evaporites $\mathrm{B}$ and $\mathrm{X}$ are given to some domestic animals such as sheep, goats, cows, horses, and camels in order to make them drink plenty of water. This is due to the presence of sodium chloride which is known to increase the palatability of food and water. Indeed, the flavors are more intense due to sodium chloride. Sodium ions stimulate the taste buds while chloride ions give the salty taste. In addition, calcite has also a therapeutic virtue for man. In fact, blue calcite is used to relax and regain your strength when fatigue sets in. Green calcite provides mental balance. Red calcite affects blood circulation and invigorates the growth of bone marrow. Calcite promotes also convalescence and stimulates the kidneys in removing toxins.

Though these Nigerien evaporites have numbers of the virtues mentioned, precautions must be taken when using them. Indeed, sodium sulphate (thenardite) is corrosive and irritant.

The percentages of insoluble and concentration of some ions contained in the evaporites studied are given in Table 2.
Table 2 showed a relatively important amount of bicarbonates ions in samples A, D, and N. This result corroborates the use of the corresponding evaporites as cooking catalysts mentioned above. The presence, in a relatively important quantity, of sodium and chloride ions in evaporites B and $\mathrm{X}$ was also observed, thus confirming their use as feed supplements for some animals. Other ions (potassium, iron, and sulphate) are also present in a low concentration in the six evaporites investigated. However, no magnesium ions were observed in samples $\mathrm{N}$ and $\mathrm{Z}$. This result agrees with the $\mathrm{X}$-rays analysis where no mineral containing these ions was detected.

Furthermore, the presence of insolubles was observed in samples $B, Z$, and $\mathrm{X}$, in relatively large amounts, but it was low in samples $\mathrm{A}$ and $\mathrm{N}$ and moderate in sample $\mathrm{D}$ (Table 2). Insolubles are also analyzed via $\mathrm{X}$-rays diffraction and the corresponding spectra are presented in Figure 3.

Minerals detected from X-ray diffraction analysis are presented in Table 3. 


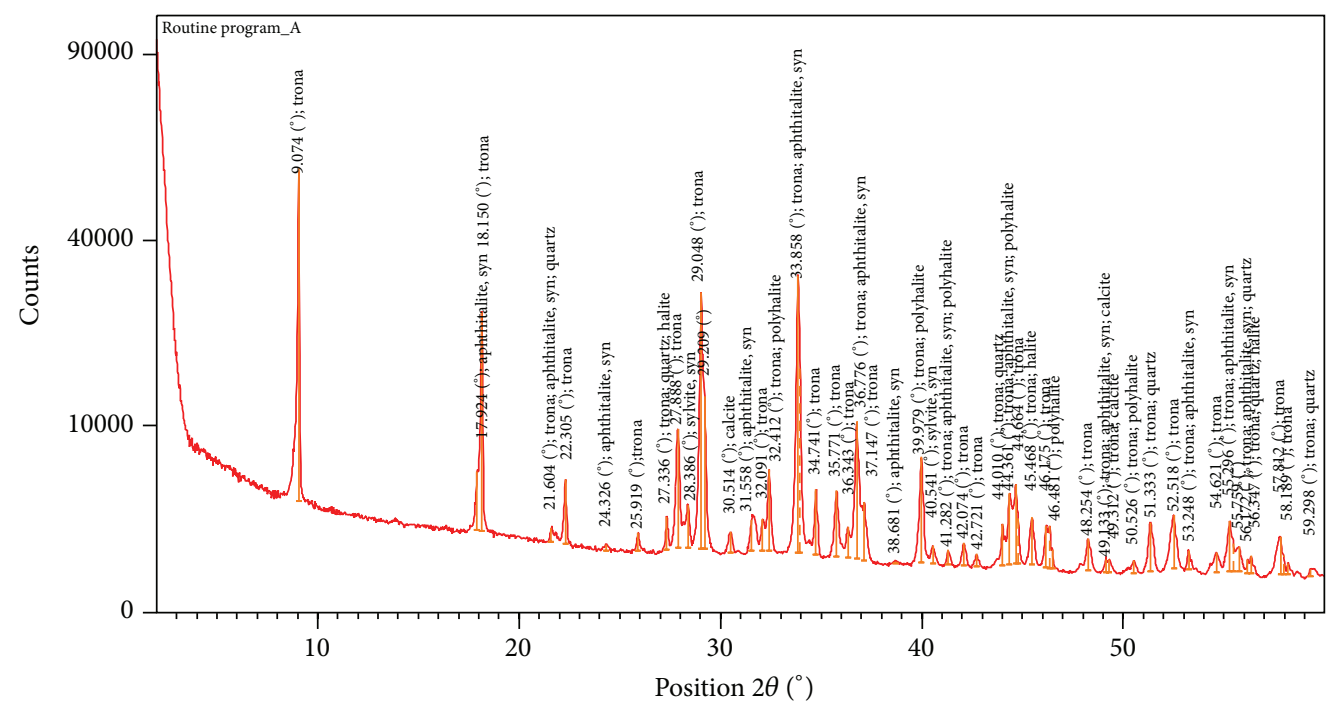

(a)

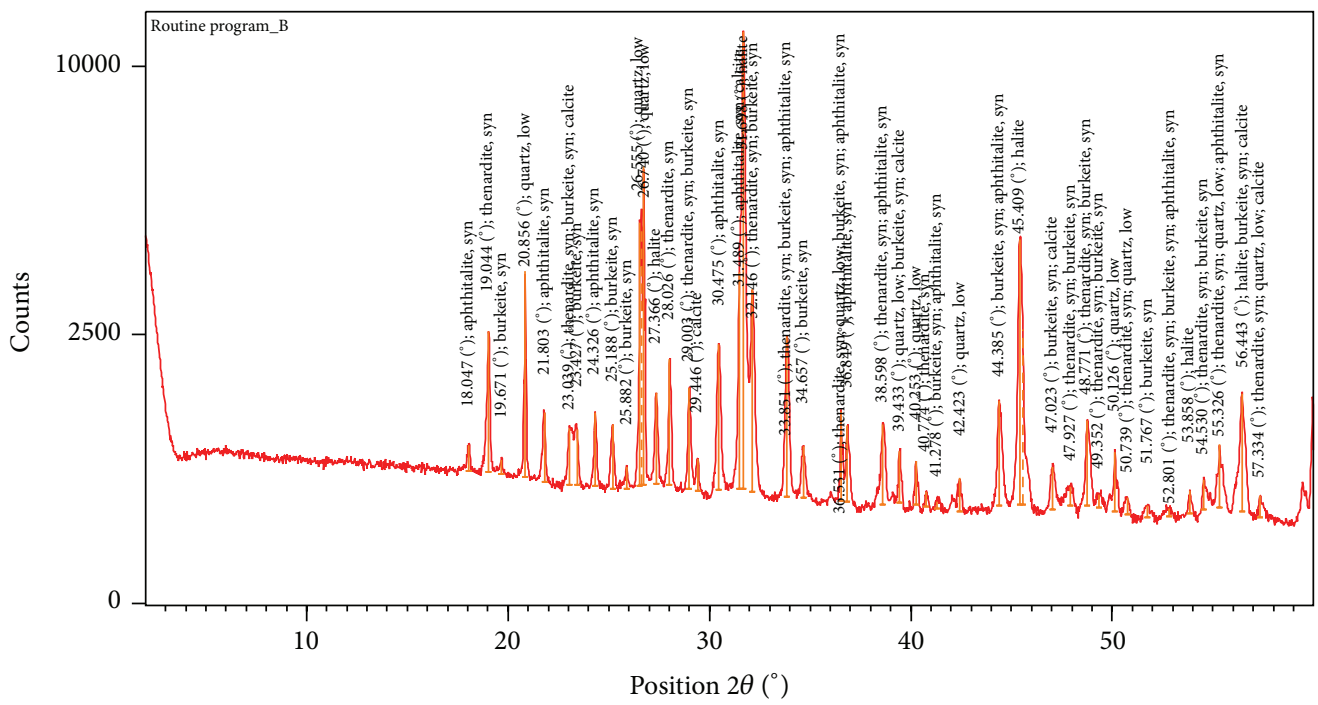

(b)

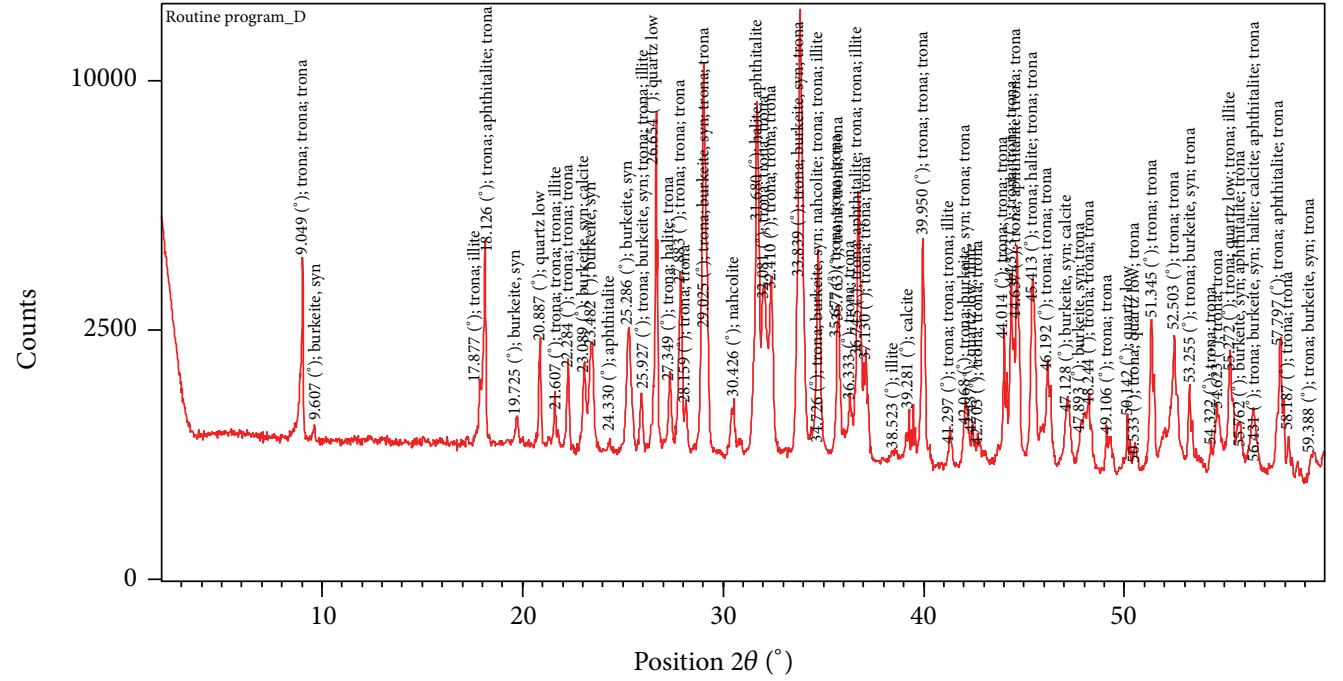

(c)

FIgure 2: Continued. 


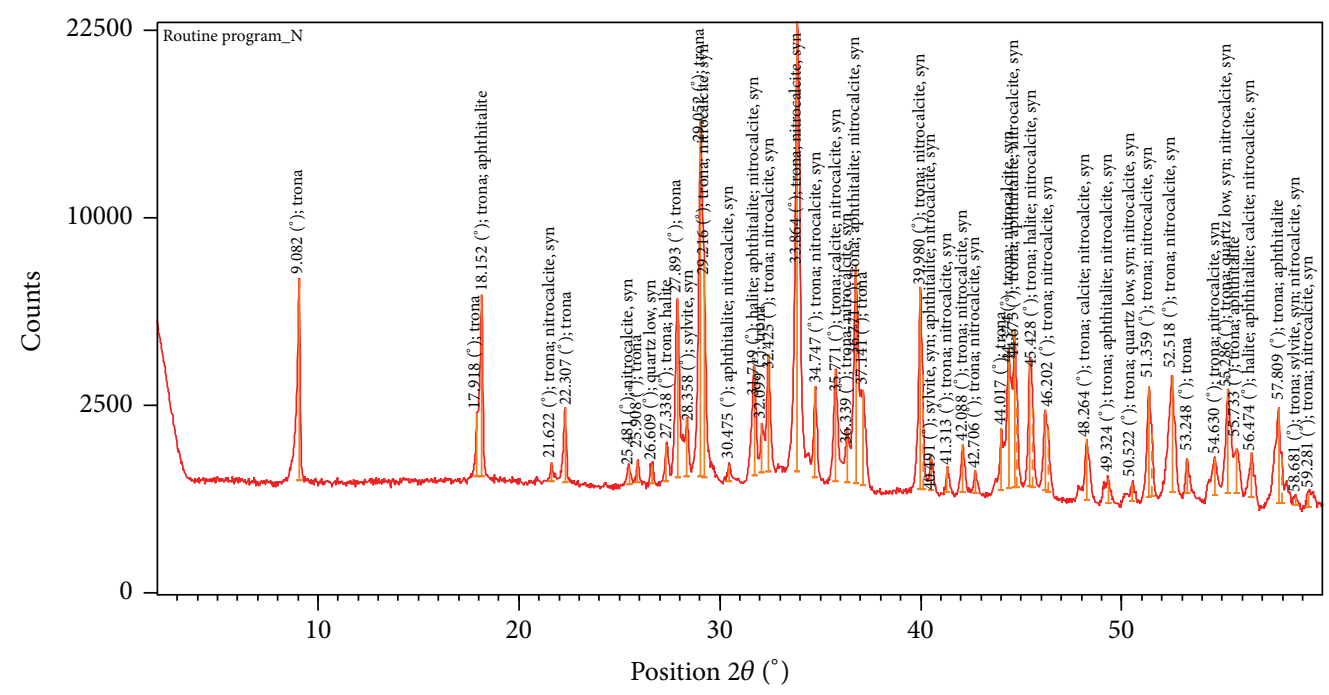

(d)

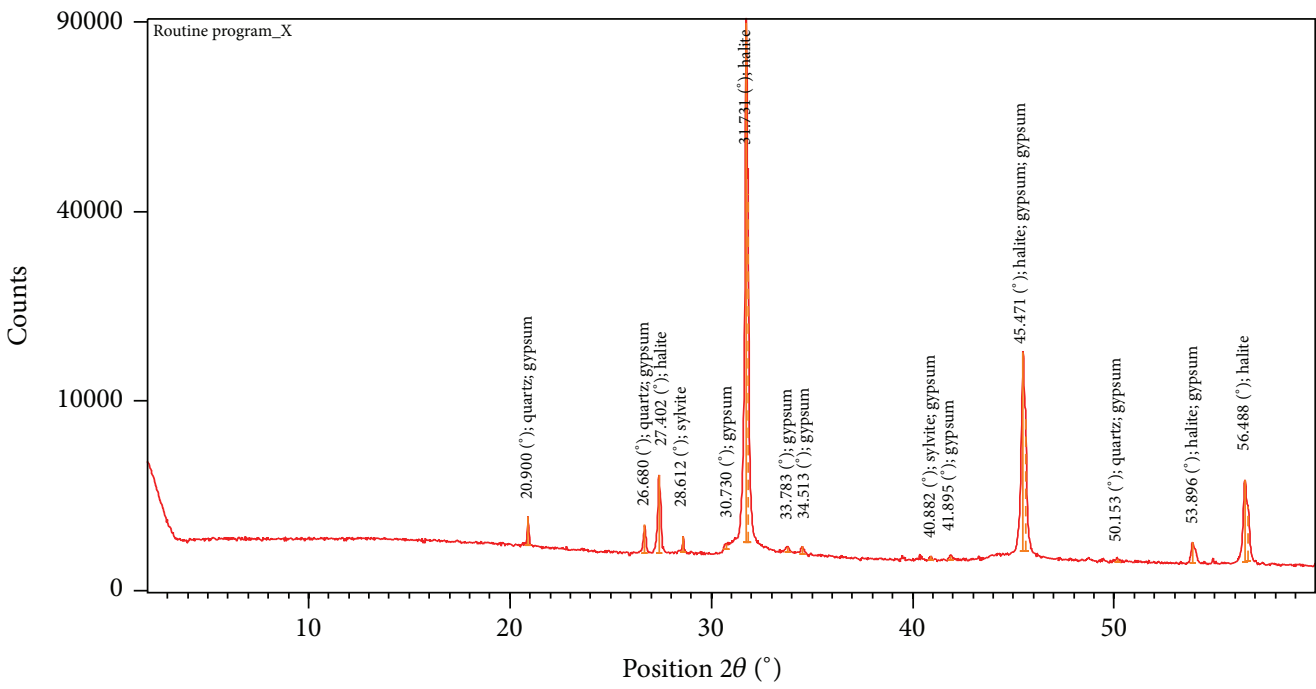

(e)

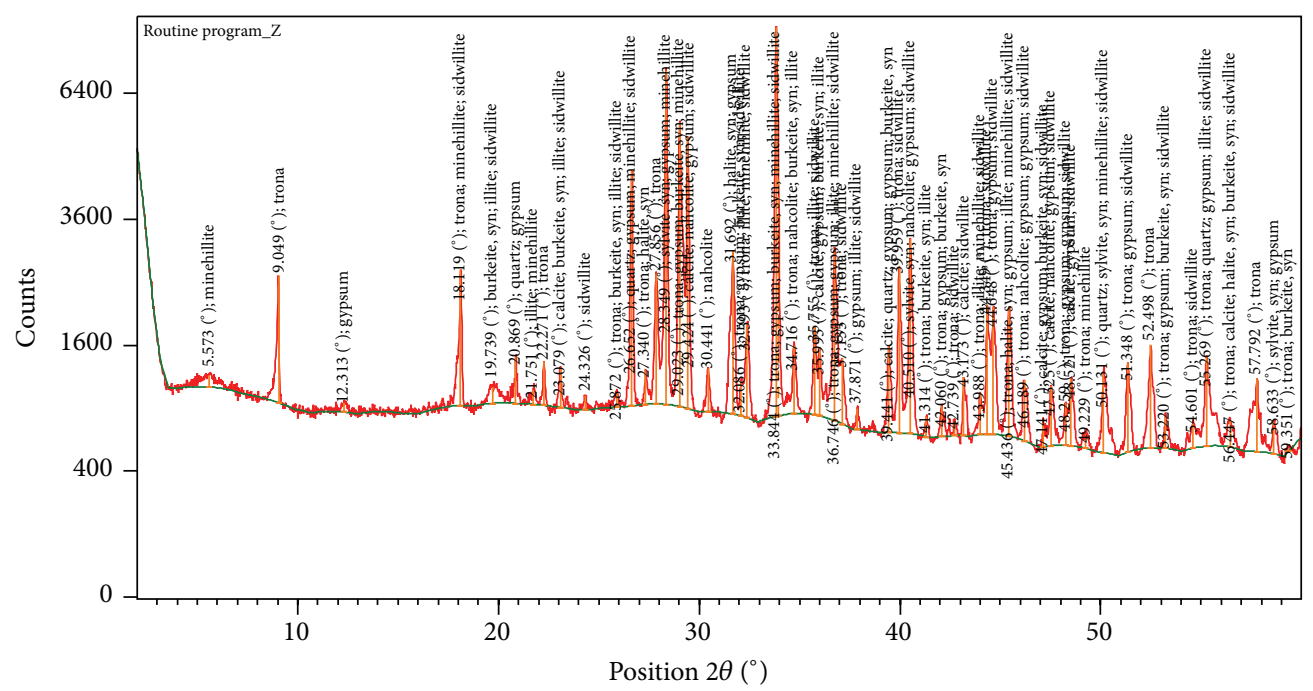

(f)

FIGURE 2: X-rays diffraction spectra of different raw samples studied. Evaporite (a) from Agadez, (b) from Bilma, (c) from Dirkou, (d) from Niamey, (e) from Tabalak, and (f) from Zinder. 


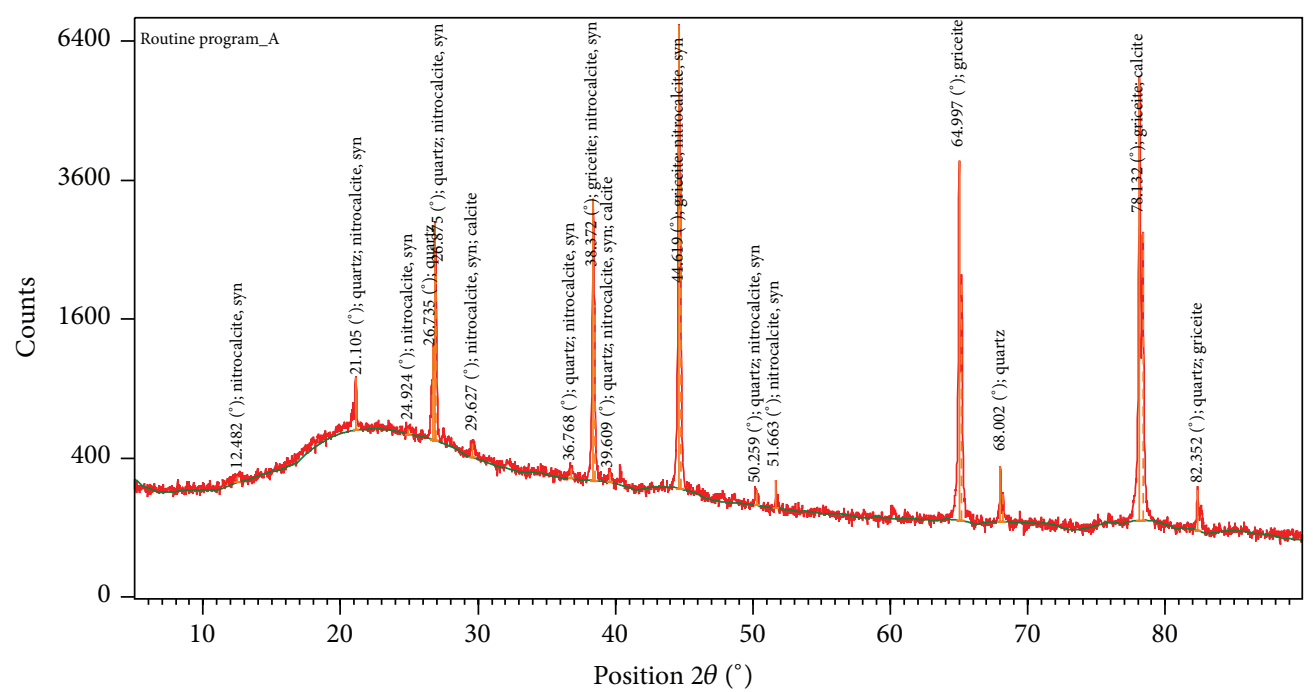

(a)

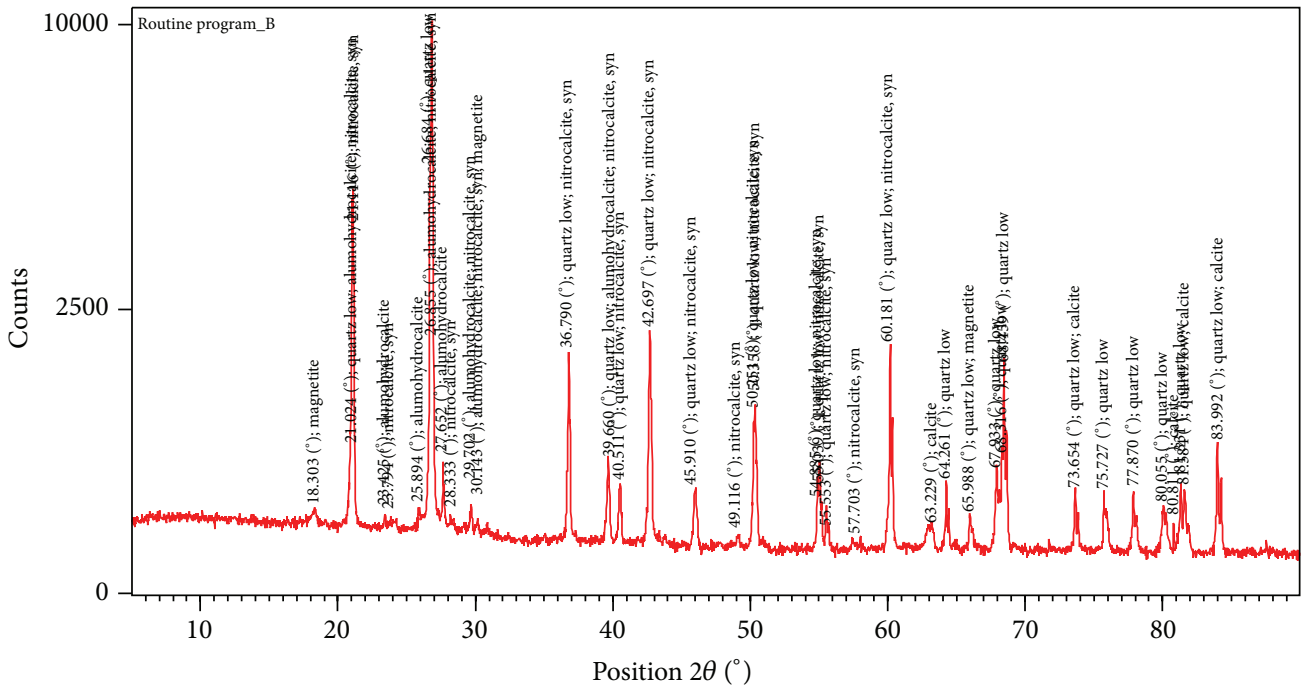

(b)

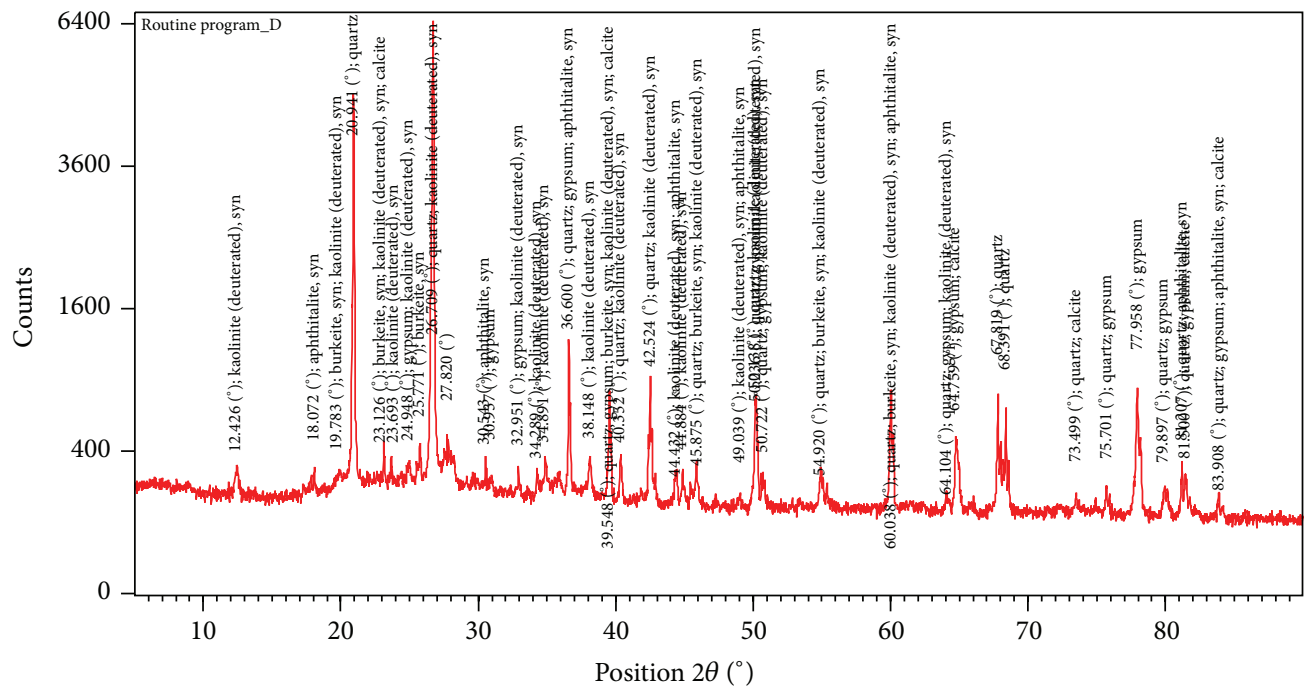

(c)

Figure 3: Continued. 


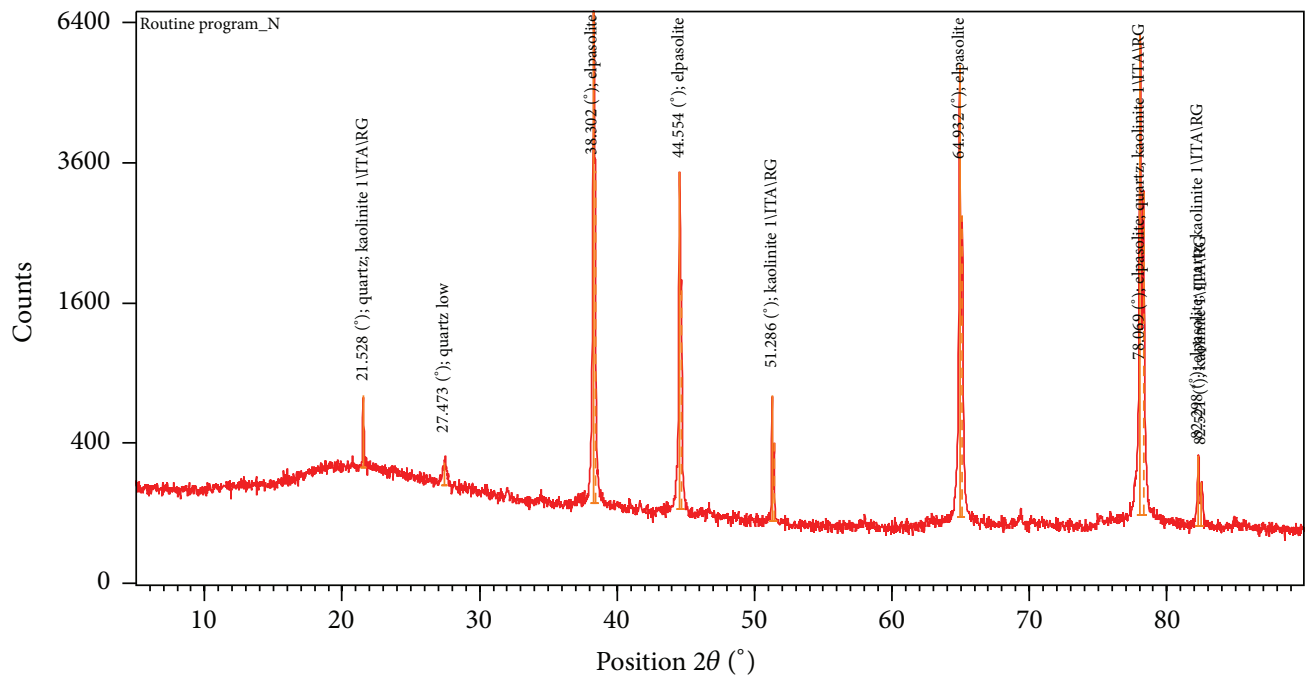

(d)

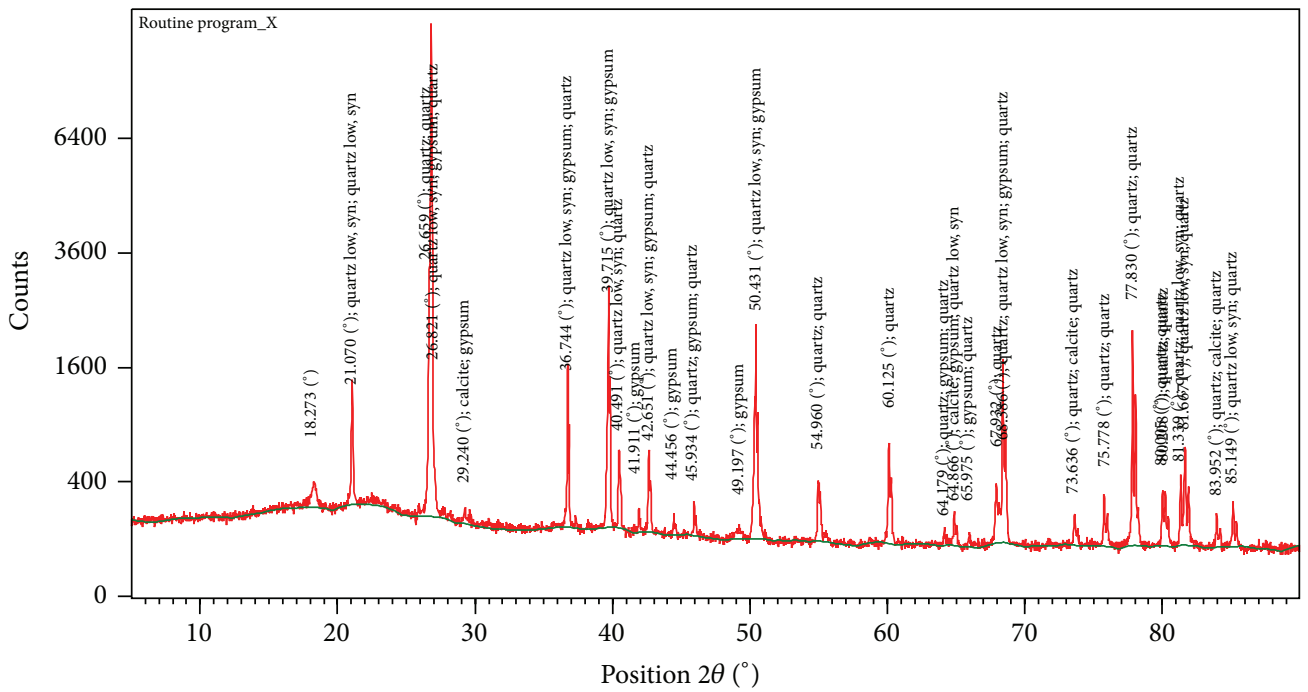

(e)

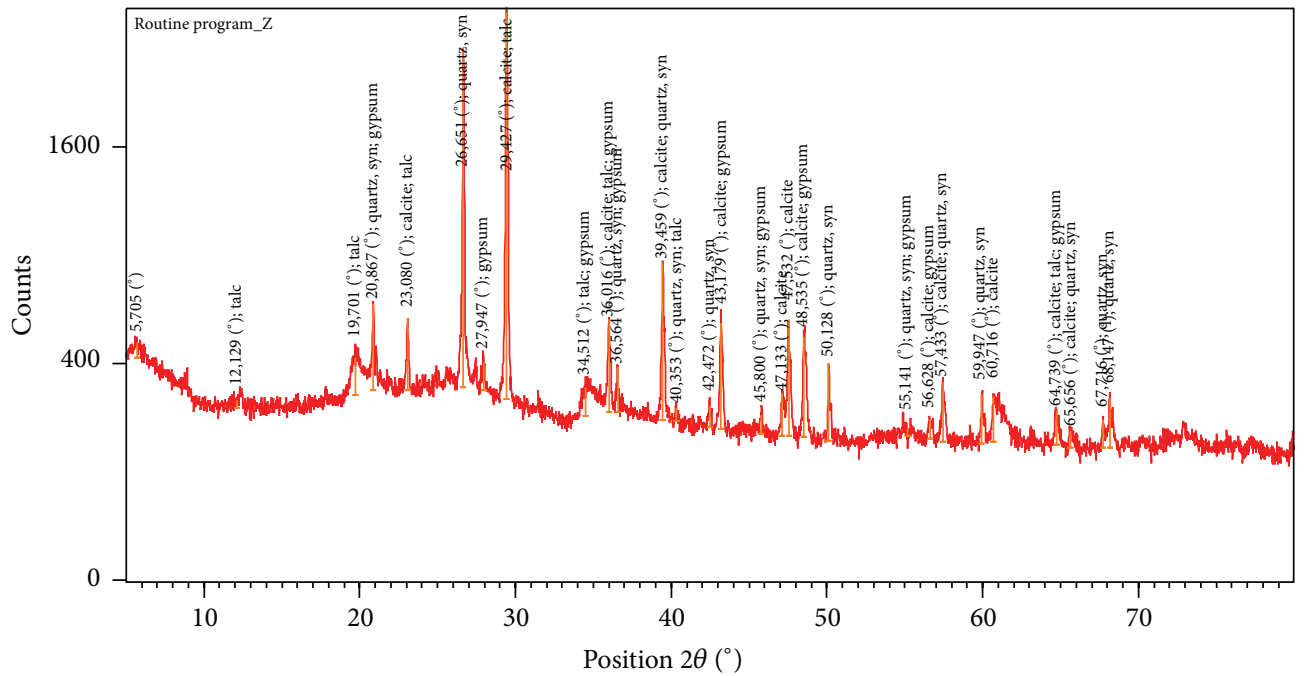

(f)

FiguRE 3: X-rays diffraction spectra of insoluble obtained. Evaporite (a) from Agadez, (b) from Bilma, (c) from Dirkou, (d) from Niamey, (e) from Tabalak, and (f) from Zinder. 


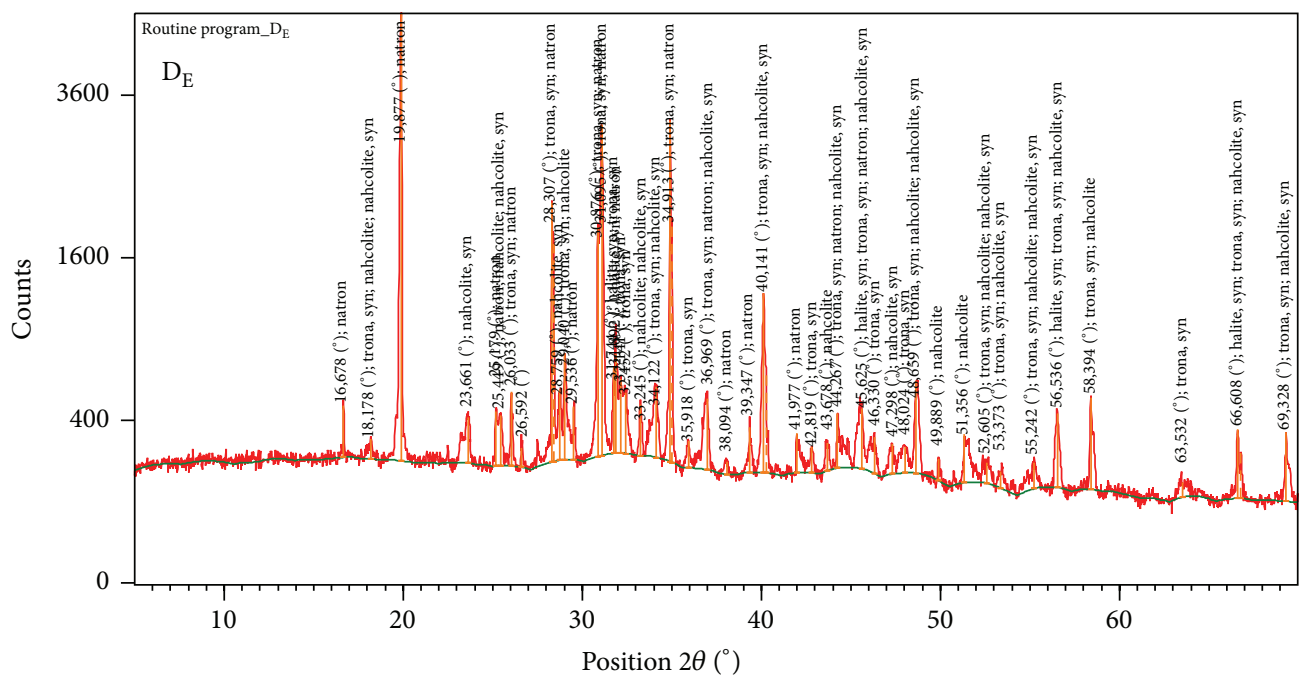

(a)

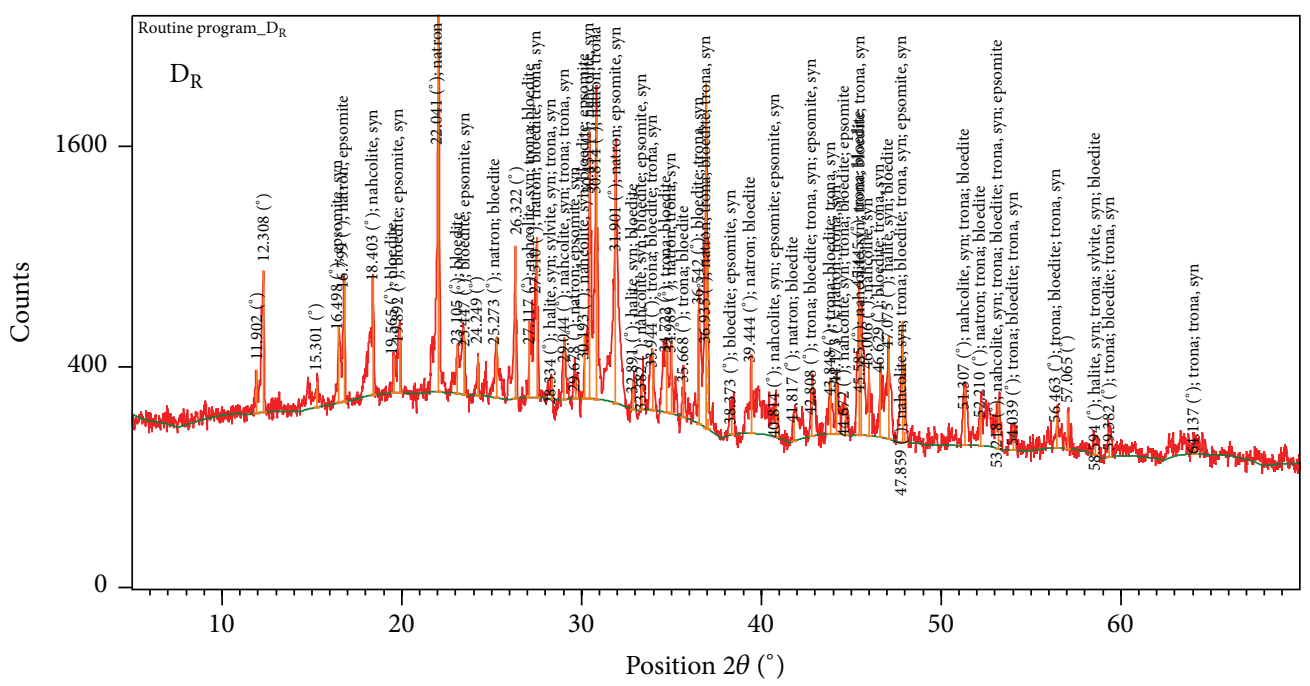

(b)

FIGURE 4: X-rays diffraction spectra of sample D filtrate obtained. $\left(D_{E}\right)$ : aerated at room temperature, $\left(D_{R}\right)$ : refrigerated.

Table 3 and Figure 3 showed that only quartz is present in all insolubles analyzed. Other minerals such as calcite $\left(\mathrm{CaCO}_{3}\right)$, gypsum $\left(\mathrm{CaSO}_{4} \cdot 2 \mathrm{H}_{2} \mathrm{O}\right)$, talc $\left(\mathrm{Mg}_{3} \mathrm{Si}_{4} \mathrm{O}_{10}(\mathrm{OH})_{2}\right)$, griceite $(\mathrm{LiF})$, and kaolinite $\left(\mathrm{Al}_{2}\left(\mathrm{Si}_{2} \mathrm{O}_{5}\right)(\mathrm{OH})_{4}\right)$ were also detected in minor proportion. Kaolinite has been used, previously, to synthesize zeolites [17]. Otherwise, griceite (LiF) present in insoluble obtained from evaporite A could be a source of lithium which is an interesting element in the energy field [18].

Basic $\mathrm{pH}$ values were obtained for all samples studied except sample $\mathrm{X}$, where $\mathrm{pH}$ value is equal to 7 , thus confirming the values of percentage of $\mathrm{HCO}_{3}{ }^{-}$obtained (Table 2). Indeed, the presence of bicarbonates ions in relatively important quantity in samples $\mathrm{A}, \mathrm{D}, \mathrm{N}$, and $\mathrm{Z}$ makes them remedies against stomach ache due to the alkalinity of these ions. These $\mathrm{HCO}_{3}{ }^{-}$ions neutralize acids released by gastric juice in the stomach.
Furthermore, the values of mass measured for each volume during density measurement experiment are presented in Table 4.

From the masses of the different volumes of sample D given in Table 4, the density of sample was determined to be $1.08 \mathrm{~g} \cdot \mathrm{cm}^{-3}$. This value means that evaporite $\mathrm{D}$ is denser than water.

The X-rays diffraction spectra of crystals obtained from sample $D$ filtrate aerated at room temperature $\left(D_{E}\right)$ and filtrate refrigerated are in Figure 4. The minerals detected are presented in Table 5.

Table 5 showed that trona, natron $\left(\mathrm{Na}_{2} \mathrm{CO}_{3} \cdot 10 \mathrm{H}_{2} \mathrm{O}\right)$, nahcolite, and halite precipitated both in filtrate aerated at room temperature $\left(D_{E}\right)$ and in filtrate refrigerated $\left(D_{R}\right)$. Filtrate refrigerated allows also the occurrence of sylvite, epsomite $\left(\mathrm{MgSO}_{4} \cdot 7 \mathrm{H}_{2} \mathrm{O}\right)$, and bloedite $\left(\mathrm{Na}_{2} \mathrm{Mg}\left(\mathrm{SO}_{4}\right)_{2} \cdot 4 \mathrm{H}_{2} \mathrm{O}\right)$. 
TABLE 3: Minerals detected from X-rays analysis of insolubles obtained ( $\times$ : mineral detected in insoluble samples studied).

\begin{tabular}{lcccccr}
\hline $\begin{array}{l}\text { Minerals } \\
\text { detected }\end{array}$ & A & B & D & N & X & $\mathrm{Z}$ \\
\hline $\begin{array}{l}\text { Trona } \\
\text { Quartz }\end{array}$ & $\times$ & $\times$ & $\times$ & $\times$ & $\times$ & $\times$ \\
Halite & & & & & & \\
Sylvite & $\times$ & $\times$ & $\times$ & & $\times$ & $\times$ \\
Calcite & $\times$ & $\times$ & & & & \\
Magnesite & $\times$ & & & & & \\
Griceite & & & $\times$ & & $\times$ & $\times$ \\
Gypsum & & & $\times$ & & & \\
$\begin{array}{l}\text { Burkeite } \\
\text { Kaolinite }\end{array}$ & & & $\times$ & $\times$ & & \\
Aphthitalite & & & $\times$ & & & \\
Elpasolite & & & & $\times$ & & \\
Talc & & & & & & $\times$ \\
\hline
\end{tabular}

TABLE 4: Masses measured and their corresponding volumes during density measurement experiment.

\begin{tabular}{lc}
\hline Mass $(\mathrm{g})$ & Volume $\left(\mathrm{cm}^{3}\right)$ \\
\hline$m_{1}=5.4036$ & 5 \\
$m_{2}=10.8578$ & 10 \\
$m_{3}=16.3177$ & 15 \\
$m_{4}=21.7400$ & 20 \\
$m_{5}=27.1705$ & 25 \\
$m_{6}=32.6034$ & 30 \\
\hline
\end{tabular}

TABLE 5: Minerals detected from X-rays diffraction analysis for crystals obtained from sample D filtrates during recrystallization experiment.

\begin{tabular}{lcc}
\hline Minerals detected & \multicolumn{2}{c}{ Filtrates } \\
\hline Trona & $\mathrm{D}_{\mathrm{E}}$ & $\mathrm{D}_{\mathrm{R}}$ \\
Natron & $\times$ & $\times$ \\
Nahcolite & $\times$ & $\times$ \\
Halite & $\times$ & $\times$ \\
Sylvite & $\times$ & $\times$ \\
Epsomite & & $\times$ \\
Bloedite & & $\times$ \\
\hline
\end{tabular}

$\times$ : minerals detected.

\section{Conclusion}

Nigerien evaporites were characterized in this study. The results obtained showed the presence of trona as major mineral in evaporites from Agadez, Dirkou, Niamey, and Zinder. However, these evaporites contain, in a significant proportion, other interesting minerals such as quartz, halite, and sylvite. Otherwise, thenardite and halite were found to be major compounds in samples from Bilma and Tabalak, respectively. The employing of evaporites from Agadez,
Dirkou, Niamey, and Zinder as cooking cowpea catalyst and stomach ache remedy is due, essentially, to an important amount of bicarbonates ions contained in these evaporites. Other complementary studies must be done to investigate if iron ions present in the evaporites studied could have an impact on human and animal health at the concentration obtained.

\section{Conflict of Interests}

The authors declare that there is no conflict of interests regarding the publication of this paper.

\section{Acknowledgments}

This work was supported by National Center for Research in Materials Sciences of Borj Cedria (Tunisia) directed by Professor Ferid Mokhtar and University of Maradi (Niger) directed by Professor Saadou Mahamane and subdirected by Professor Mahamane Ali. It took place at the laboratory of recovery of valuable materials directed by Professor Adel Mnif. All staff members of the center and University of Maradi receive the authors' gratitude.

\section{References}

[1] T. Zouaghi, M. Bédir, A. Ayed-Khaled et al., "Autochthonous versus allochthonous Upper Triassic evaporites in the Sbiba graben, central Tunisia," Journal of Structural Geology, vol. 52, no. 1, pp. 163-182, 2013.

[2] D. Cordier, J. W. Barnes, and A. G. Ferreira, "On the chemical composition of Titan's dry lakebed evaporites," Icarus, vol. 226, no. 2, pp. 1431-143, 2013.

[3] J. Alonso-Azcárate, S. H. Bottrell, and J. R. Mas, "Synsedimentary versus metamorphic control of $\mathrm{S}, \mathrm{O}$ and $\mathrm{Sr}$ isotopic compositions in gypsum evaporites from the Cameros Basin, Spain," Chemical Geology, vol. 234, no. 1-2, pp. 46-57, 2006.

[4] R. P. Martin, H. Cahit, and E. F. Anthony, "Sulphur, sulphate oxygen and strontium isotope composition of Cenozoic Turkish evaporites," Chemical Geology, vol. 209, no. 3-4, pp. 341-356, 2004.

[5] A. A. Makanjuola and J. G. J. Beetlestone, "Some chemical and mineralogical notes on kaun (trona)," Journal of Mining Geology, vol. 10, no. 1-2, pp. 31-41, 1975.

[6] M. O. Iwunze, "A preliminary analysis of the constituents of the Nigerian Crude Potash," Nigerian Journal of Science and Technology, vol. 4, pp. 64-70, 1998.

[7] K. G. Papke, Evaporites and Brines in Nevada Playas, vol. 87 of Bulletin-Nevada Bureau of Mines and Geology, 1976.

[8] G. Papke, "Gypsum deposits in Nevada," Bulletin 103, Nevada Bureau of Mines and Geology, 1987.

[9] B. H. Baker, "Geology of the Magadi area," Geological Survey of Kenya, vol. 1, no. 42, pp. 5-6, 1958.

[10] E. K. Ankrah and F. E. J. Dovlo, "The properties of trona and its effect on the cooking time of cowpeas," Journal of the Science of Food and Agriculture, vol. 29, no. 11, pp. 950-952, 1978.

[11] L. Mabelya, K. G. König, and W. H. V. P. Helderman, "Dental fluorosis, altitude, and associated dietary factors," Caries Research, vol. 26, no. 1, pp. 65-67, 1992. 
[12] L. C. Emebiri and M. I. Nwufo, "Effect of Trona (Urao) on the survival and reproduction of Sitophilus zeamais and Tribolium castaneum on stored maize," Agriculture, Ecosystems and Environment, vol. 32, no. 1-2, pp. 69-75, 1990.

[13] J. M. Nielsen, "East African magadi (trona): Fluoride concentration and mineralogical composition," Journal of African Earth Sciences, vol. 29, no. 2, pp. 423-428, 1999.

[14] F. Khlissa, A. M'nif, and R. Rokbani, "Application of the conductimetry to the study of the transformation of $\mathrm{KCl}$ and $\mathrm{Na}_{2} \mathrm{SO}_{4}$ into $\mathrm{K}_{2} \mathrm{SO}_{4}$ between 5 and $30^{\circ} \mathrm{C}$," Chemical Engineering and Processing: Process Intensification, vol. 43, no. 7, pp. 929-934, 2004.

[15] S. G. Uzogara, I. D. Morton, J. W. Daniel, and P. W. J. Emery, "Use of kanwa-cooked cowpea (Vigna unguiculate) in infant food formulation: effect of protein utilization and digestibility [letter]," Journal of Tropical Pediatrics, vol. 36, no. 4, pp. 207208, 1990.

[16] O. A. Sodipo, "How safe is the consumption of trona?" American Journal of Public Health, vol. 83, no. 8, article 1181, 1993.

[17] C. Belviso, F. Cavalcante, A. Lettino, and S. Fiore, "A and X-type zeolites synthesised from kaolinite at low temperature," Applied Clay Science, vol. 80-81, pp. 162-168, 2013.

[18] B. Markovsky, A. Rodkin, Y. S. Cohen et al., "The study of capacity fading processes of Li-ion batteries: major factors that play a role," Journal of Power Sources, vol. 119-121, pp. 504-510, 2003. 

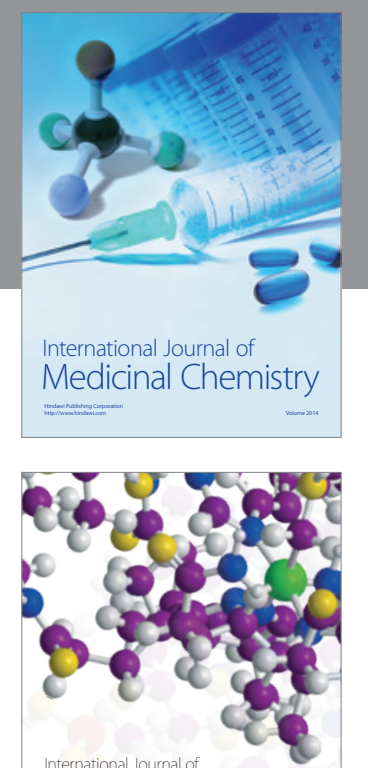

\section{Carbohydrate} Chemistry

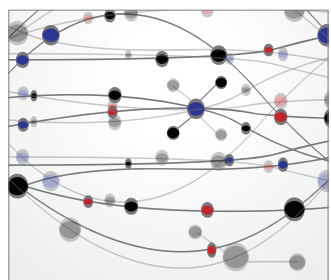

The Scientific World Journal
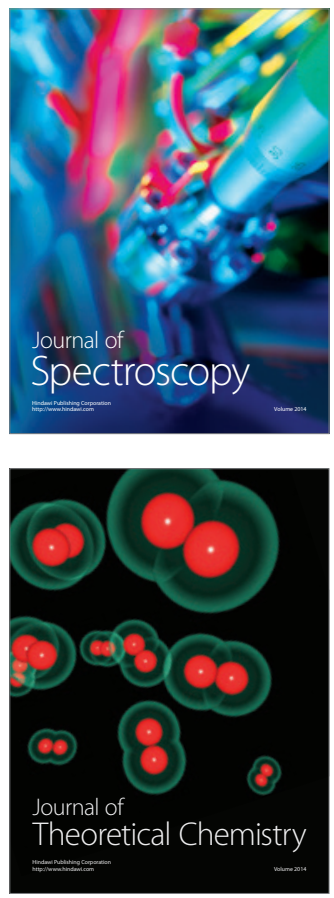
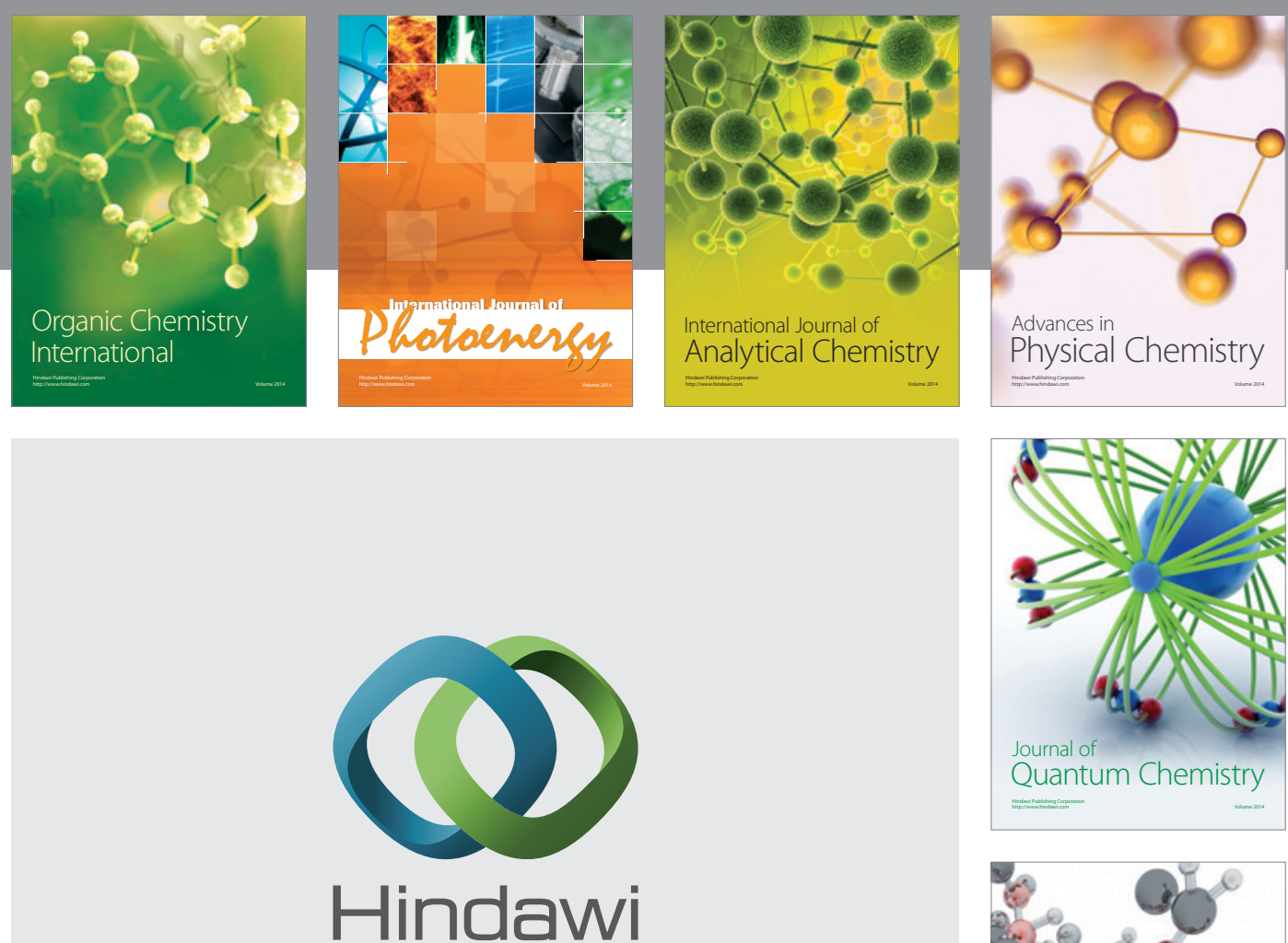

Submit your manuscripts at

http://www.hindawi.com

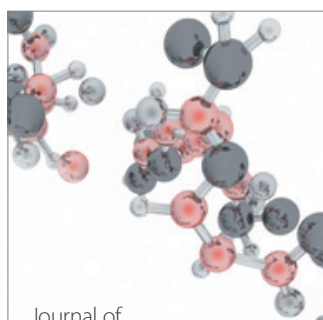

Analytical Methods

in Chemistry

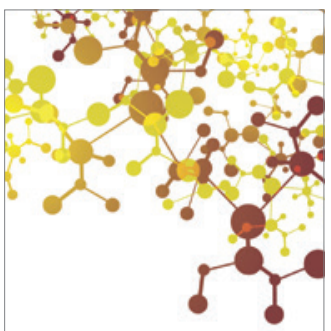

Journal of

Applied Chemistry

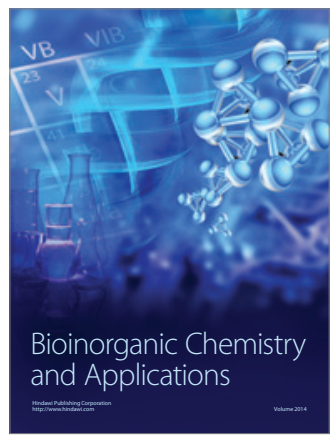

Inorganic Chemistry
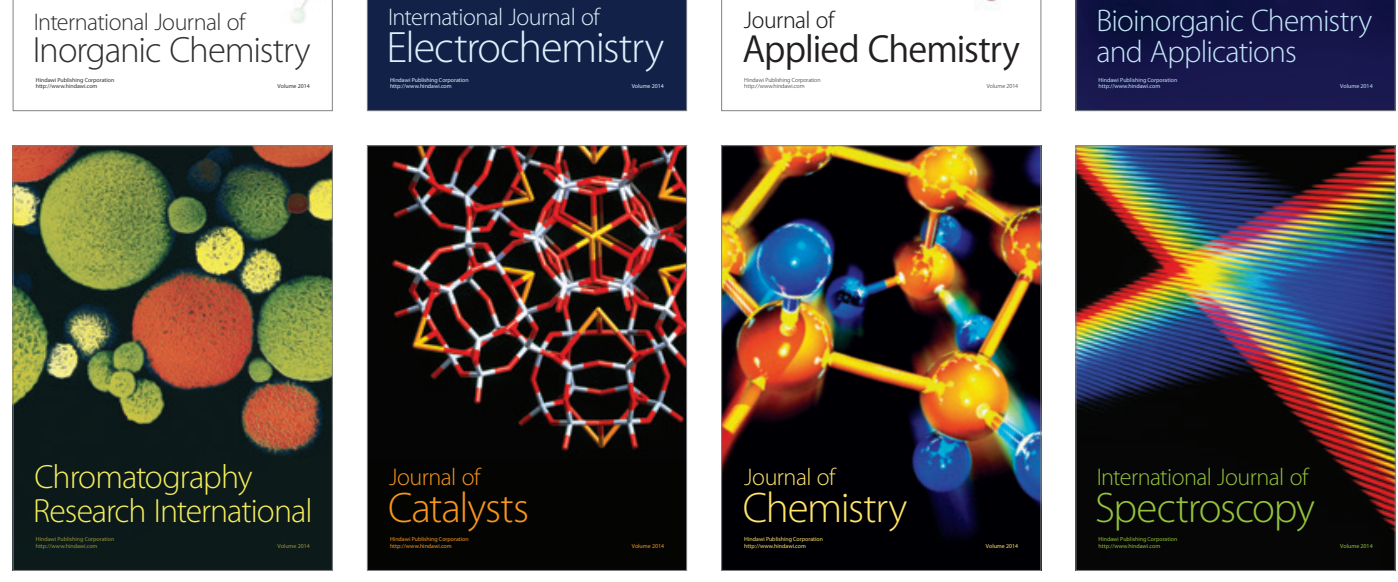